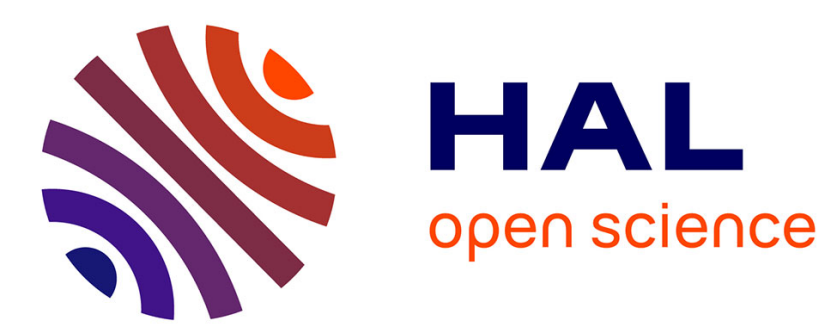

\title{
How group feeding influences intake level of hay and feeding behaviour of beef cows
}

Stéphane Ingranda, Jacques Agabriel, Jacques Lassalas, Benoit Dedieu

\section{To cite this version:}

Stéphane Ingranda, Jacques Agabriel, Jacques Lassalas, Benoit Dedieu. How group feeding influences intake level of hay and feeding behaviour of beef cows. Annales de zootechnie, 1999, 48 (6), pp.435-445. hal-00889816

\section{HAL Id: hal-00889816 https://hal.science/hal-00889816}

Submitted on 1 Jan 1999

HAL is a multi-disciplinary open access archive for the deposit and dissemination of scientific research documents, whether they are published or not. The documents may come from teaching and research institutions in France or abroad, or from public or private research centers.
L'archive ouverte pluridisciplinaire HAL, est destinée au dépôt et à la diffusion de documents scientifiques de niveau recherche, publiés ou non, émanant des établissements d'enseignement et de recherche français ou étrangers, des laboratoires publics ou privés. 


\title{
How group feeding influences intake level of hay and feeding behaviour of beef cows
}

\author{
Stéphane Ingrand ${ }^{\mathrm{a} *}$, Jacques Agabriel ${ }^{\mathrm{b}}$, Jacques Lassalas ${ }^{\mathrm{b}}$, \\ Benoît Dedieu ${ }^{a}$ \\ a Départements SAD et ENA, ${ }^{\mathrm{b}}$ Département ENA, \\ Unité de recherches sur les herbivores, Institut national de la recherche agronomique, \\ 63122 Saint-Genès-Champanelle, France
}

(Received 19 February 1999; accepted 10 September 1999)

\begin{abstract}
During winter, beef cows in large herds are now more often accommodated with group feeding systems. However, the recommended allowances for feeding beef cows are primarily based on results obtained with tethered animals. The feed intake and feeding behaviour of 47 Charolais cows fed hay ad libitum were thus compared over two successive winters in a stanchion tie-stall system (TS) and in a loose housing system (LH) using 24 barren dry cows and 23 lactating cows. Loose-housed cows consumed $0.8 \mathrm{~kg}$ of dry matter (DM) less than tethered cows. This difference depended on the physiological state of the cows. Barren dry cows had a similar daily voluntary intake in both housing systems, but spent 35 min longer eating in the LH system. Lactating cows spent the same time ( $5 \mathrm{~h} 50 \mathrm{~min}$ ) eating in both housing systems but ate $1.1 \mathrm{~kg}$ of DM less in the LH system. There was a substantial individual variability for the modifications of intake and feeding behaviour between tethered and loose-housed systems. This variability seemed to be dependent upon the individual nutritional requirements of the cows. The small leanest cows, having a low milk yield, increased their intake when loose-housed. They also maintained their rate of intake, which decreased for about 7 to $8 \mathrm{~g} \mathrm{DM} \cdot \mathrm{min}^{-1}$ for their counterparts with high requirements. (을 Elsevier / Inra)
\end{abstract}

\section{beef cow / feed intake / feeding behaviour / individual feeding / group feeding}

Résumé - Effets de l'alimentation en groupe sur le niveau d'ingestion et le comportement alimentaire de vaches Charolaises. Durant l'hiver, les vaches reproductrices des troupeaux allaitants de grande taille sont le plus souvent conduites en stabulation libre et alimentées collectivement. Les recommandations alimentaires pour ces vaches sont cependant basées exclusivement sur des résultats obtenus en stabulation entravée. Le niveau d'ingestion et le comportement alimentaire de 47 vaches Charolaises ( 24 vaches taries et 23 vaches en lactation) nourries au foin à volonté ont été comparés durant deux hivers consécutifs à l'attache et en stabulation libre (cross-over avec des

\footnotetext{
* Correspondence and reprints

tel: (33) 0473624291 ; fax: (33) 0473624118 ; ingrand@clermont.inra.fr
} 
groupes de 6 vaches à même état physiologique). Les vaches ont consommé en moyenne $800 \mathrm{~g}$ de MS $\cdot j^{-1}$ en moins en stabulation libre : la différence $n$ 'a pas été significative pour les vaches taries $(500 \mathrm{~g})$, contrairement aux vaches en lactation $(1100 \mathrm{~g} ; p<0,05)$. La durée d'ingestion des vaches taries a été supérieure de $35 \mathrm{~min}$ en stabulation libre $(p<0,05)$, alors qu'elle a été équivalente pour les vaches en lactation ( 5 h 50 en moyenne). La vitesse d'ingestion a été plus faible en stabulation libre pour les vaches des deux stades physiologiques. La variabilité individuelle des réponses a été importante, en relation avec le niveau des besoins nutritionnels des vaches. Ainsi, les petites vaches les plus maigres, produisant peu de lait pour celles qui étaient en lactation, ont augmenté leur niveau d'ingestion en stabulation libre, contrairement aux autres. Elles ont également maintenu leur vitesse d'ingestion, alors que les autres l'ont diminué en moyenne de 7 à $8 \mathrm{~g}$ de $\mathrm{MS} \cdot \mathrm{min}^{-1}$. Il existe donc un «effet groupe » sur le niveau d'ingestion et les paramètres du comportement alimentaire, en interaction avec le niveau des besoins nutritionnels des vaches. (ङ Elsevier / Inra)

vache allaitante / quantités ingérées / comportement alimentaire / individu / groupe

\section{INTRODUCTION}

In France, there is a trend towards increasing suckler herd size, and this has led to specific changes in rearing practice, which include fewer batches of greater size, with less frequent modification of batches $[14,15]$. During winter, cows in large herds are now more often accommodated in loose housing systems with group feeding systems. The recommended allowances for feeding suckler cows [23] are primarily based on results obtained with tethered animals for which it is easy to obtain individual data. Individuals are then considered as independent for statistical analyses. The predictive equations for intake include live weight, body condition score and milk yield [1] but not social effects (dominance, social facilitation) which arise in group feeding. The models for individual nutritional requirements are applicable to the average animal in a specified group [11], assuming that the group is as homogeneous as possible. It is also assumed in the current equations that animals in loose housing systems have 10 to $15 \%$ greater energy requirements than those in tie-stall systems due to more exercise [3, 17, 23]. Comparative studies of individual and group feeding have included dairy catthe $[5,7,22]$ and growing cattle $[6,17]$, but there are no published reports on the feeding behaviour and voluntary intake of hay by individual suckler cows offered feed as a group.

The aim of this paper is to compare the feed intake and feeding behaviour of suckler cows in a stanchion system (individual feeding), and in a loose housing system (group feeding), with particular attention to individual cows in groups. Thus, one objective is to determine if the behaviour of cows penned individually can be representative of similar animals kept in groups [26].

\section{MATERIAL AND METHODS}

\subsection{Animals, feed, measurements}

Forty-seven Charolais cows (24 barren dry cows and 23 lactating cows) were involved in a trial conducted at the Laqueuille experimental farm (Inra, Puy-De-Dôme, France) during two successive winters (1995/96: calving between 29 December and 17 January, and 1996/97: calving between 24 December and 25 January). Each winter, for cows in each physiological state, two treatments were applied using a cross-over design involving 4-week periods and batches of six cows at the same physiological state (only five cows in one batch of lactating cows in winter 1996/97 because one cow was removed from the experiment). The two treatments were 1) individual feeding in a tie-stall (TS) system (slatted floor) and 2) group feeding in a loose housing ( $\mathrm{LH}$ ) system (slatted floor and straw bedding). All 
cows were fed ad libitum with a natural grass hay (10 to $15 \%$ refusal), in two daily feedings at 10.00 and 16.00 hours. The cows had free access to water and minerals. The amount of hay harvested as a single batch was insufficient and thus, each winter, barren and lactating cows were offered different hays, resulting in a total of four different hays offered. Samples $(500 \mathrm{~g}$ ) of hay offered and refused were taken twice weekly and dried at $80^{\circ} \mathrm{C}$ to estimate dry matter (DM) concentration. Dried samples were retained for subsequent chemical analysis (table I) [4]. To take into account the different types of hays, intake data were corrected relative to the hay having the smallest fill value (hay 2) [18]. The correction coefficients were $1.009,1.061$ and 1.035 for hays 1, 3 and 4, respectively (table $I$ ).

In the stanchion system, hay offered and refusals were weighed from Monday to Thursday and from Tuesday to Friday, respectively. Hence, four individual daily data points per week were available for TS cows. In the loose housing system, individual records of feed consumed was obtained daily using an electronic system, named 'Solot' [16], similar to that described by Forbes et al. [11]. The hay was placed into mangers (one manger per cow) and automatically weighed by compression-type load cells. Each access (one per manger) was fitted with a loop which energizes the transponder of any cow feeding in the manger. The corresponding identity of the animal was transmitted to a microcomputer and a file was appended with the time, the cow's identity and the manger's weight (one file per manger). The time lapse between two scans of each manger by the computer is about 5 to $10 \mathrm{~s}$.

Animals were videotaped for $24 \mathrm{~h}$ per day over periods of 5 days for each treatment to determine feeding behaviour in the stanchion system (time, duration and frequency of meals) and to estimate the social rank of each cow in the loose- housed group. The behaviour used to establish dominance was the replacements among cows around the mangers (priority of access to food). The social rank for each cow in the group was then obtained by assigning the two most dominant cows to rank 1, the two medium cows to rank 2 and the two most submissive cows to rank 3 . Video recording also allowed control of the data registered with the automatic monitoring. The results showed that the two systems were in accordance [16].

The cows were weighed twice per month. Body size was assessed by measuring height at withers, chest depth and width at trochanter once each winter with a measuring stick. Body condition was estimated at the beginning and end of the trials by giving a score from 0 to 5 [2]. Calves were not allowed continuous access to the cows and milk production of lactating cows was estimated every 15 days by weighing calves before and after suckling in the morning (07.30 hours) and in the evening (16.30 hours) [21].

There was no significant difference between barren and lactating cows in liveweight, or width at trochanter but barren cows had a greater chest depth (table $I I$ ). Average body condition score

Table II. Characteristics of the cows.

\begin{tabular}{lcc}
\hline $\begin{array}{l}\text { Type of cows } \\
\text { Number of cows }\end{array}$ & $\begin{array}{c}\text { Barren } \\
24\end{array}$ & $\begin{array}{c}\text { Lactating } \\
23\end{array}$ \\
\hline Body weight $(\mathrm{kg})$ & $785 \pm 77$ & $767 \pm 51$ \\
Height at withers $(\mathrm{cm})$ & $134 \pm 5$ & $135 \pm 2$ \\
Width at trochanter $(\mathrm{cm})$ & $57 \pm 3$ & $56 \pm 3$ \\
Chest depth $(\mathrm{cm})$ & $78 \pm 3$ & $75 \pm 2$ \\
Milk production $\left(\mathrm{kg} \cdot \mathrm{d}^{-1}\right)$ & & $7.9 \pm 1.2$ \\
Body condition score $(0$ to 5$)$ & $2.5 \pm 0.4$ & $2.1 \pm 0.3$ \\
\hline
\end{tabular}

Table I. Chemical composition of hays.

\begin{tabular}{lcccccccc}
\hline $\begin{array}{l}\text { Year } \\
\text { (winter) }\end{array}$ & Hay & $\begin{array}{c}\text { Type of } \\
\text { cows }\end{array}$ & $\begin{array}{c}\text { OM } \\
\left(\mathrm{g} \cdot \mathrm{kg}^{-1} \mathrm{DM}\right)\end{array}$ & $\begin{array}{c}\mathrm{DMd} \\
(\%)\end{array}$ & $\begin{array}{c}\mathrm{CP} \\
\left(\mathrm{g} \cdot \mathrm{kg}^{-1} \mathrm{DM}\right)\end{array}$ & $\begin{array}{c}\mathrm{CF} \\
\left(\mathrm{g} \cdot \mathrm{kg}^{-1} \mathrm{DM}\right)\end{array}$ & $\begin{array}{c}\mathrm{NEL} \\
\left(\mathrm{MJ} \cdot \mathrm{kg}^{-1} \mathrm{DM}\right)\end{array}$ & $\mathrm{FU}$ \\
\hline $1995 / 96$ & 1 & Barren & 928 & 59.3 & 116 & 334 & 5.07 & 1.15 \\
$1995 / 96$ & 2 & Lactating & 943 & 59.7 & 120 & 342 & 5.11 & 1.14 \\
$1996 / 97$ & 3 & Barren & 947 & 57.6 & 97 & 358 & 4.86 & 1.21 \\
$1996 / 97$ & 4 & Lactating & 930 & 59.0 & 102 & 349 & 5.02 & 1.18 \\
\hline
\end{tabular}

OM: organic matter; DM: dry matter; DMd: digestibility of dry matter; CP: crude protein; CF: crude fibre; NEL: net energy for lactation; FU: fill value for cattle. 
was $2.5 \pm 0.4$ and $2.1 \pm 0.3$, respectively, for barren and lactating cows $(P>0.05)$. The milk production level for lactating cows was $7.9 \pm 1.24 \mathrm{~kg} \cdot \mathrm{d}^{-1}$, in agreement with classical values obtained for the Charolais breed.

\subsection{Data analysis}

Dependant variables used in the analyses were individual data: daily intake level, daily duration of eating, daily rate of eating, number of short and long meals, synchronisation of eating activity and eating duration per hour. The daily rate of eating was calculated by dividing the daily intake level by the daily duration of eating. The synchronisation of eating activities was assessed by calculating every minute (from data on feeding bouts) and for each cow the number of counterparts eating at the same time [28]. If one cow always ate alone, the corresponding value would be 1; if one cow always ate with all the others, this value would be 6 (group size). Meals were determined with a 5-min interval criterion (to account for differences between intra- and intermeal intervals). Long and short meals were distinguished according to their duration: more or less than $1 \mathrm{~h}$. The 24-h period was divided into three parts: P1, from 07.00 to 15.00 hours (around first feeding in the morning), P2, from 15.00 to 23.00 hours (around second feeding in the evening) and P3, from 23.00 to 07.00 hours (night).

Effects of treatment (TS and LH) were analysed on average for the batch and individually for each cow in the batch. In the first case, a SAS mixed procedure [27] was performed to analyse the effect of treatments for batches, according to the physiological state of cows. By using the SAS Mixed procedure, individual measurements were used for cows kept in the group, assuming that interactions between individuals were the same whatever the animal. The fixed effects included in the model were the year (confounded with the hay for each physiological state), the feeding system and the physiological state. The cow within the group was included as a random effect.

In the second case, cows were clustered according to the differences in feeding behaviour between the two housing systems for the following variables (value in TS minus value in LH): intake level, eating time, number of long and short meals, synchronisation of eating activity. It combined a principal component analysis (PCA) and a cluster analysis using principal com- ponent scores [20]. The clusters were then described and compared (SAS GLM), using the characteristics of the cows (physiological state, size, body weight, body condition, milk production level, social rank).

\section{RESULTS}

\subsection{Tie stall vs. loose housing for the batch (table III)}

The average daily intake level over the 2 years was $13.2 \mathrm{~kg} \mathrm{DM}$ for barren cows (range: 10.5 to 15.7 ) and $15.8 \mathrm{~kg} \mathrm{DM}$ for lactating cows (range: 11.7 to 18.5). Cows ate on average $0.8 \mathrm{~kg}$ less DM in the $\mathrm{LH}$ system $(P<0.05)$. This difference was not significant for barren cows, but the lactating cows ate $1.1 \mathrm{~kg}$ DM less in the LH system $(P<0.01)$. The difference in intake between housing systems was positively correlated to intake level in the TS system (figure I) and the lower the intake when tethered, the higher the increase when loose-housed.

The average daily duration of eating was $326 \mathrm{~min}$. It did not differ between treatments for lactating cows, but barren cows in the LH system spent more time eating than in the TS system (35 $\mathrm{min} \cdot \mathrm{d}^{-1} ; P<0.05$ ). Lactating cows spent $64 \mathrm{~min} \cdot \mathrm{d}^{-1}$ more eating than barren cows in the TS system versus only $31 \mathrm{~min} \cdot \mathrm{d}^{-1}$ more in the LH system.

The average rate of eating was $44 \mathrm{~g} \cdot \mathrm{min}^{-1}$. Both types of cows ate more rapidly in the TS system than in the LH system, especially barren cows ( 50 vs. $43 \mathrm{~g} \mathrm{DM} \cdot \mathrm{min}^{-1}$, respectively). Lactating cows had the same rate of eating than barren cows in the LH system ( $44 \mathrm{vs} .43 \mathrm{~g} \cdot \mathrm{min}^{-1}$, respectively), but not in the TS system (47 vs. $50 \mathrm{~g} \cdot \mathrm{min}^{-1}$, respectively).

The number of daily meals differed only for barren cows, which had fewer long meals when loose-housed. Lactating cows had fewer and longer small meals in the morning (P1) and longer short meals and more long meals during the night (P3) when they were loose-housed. Barren cows had fewer long 


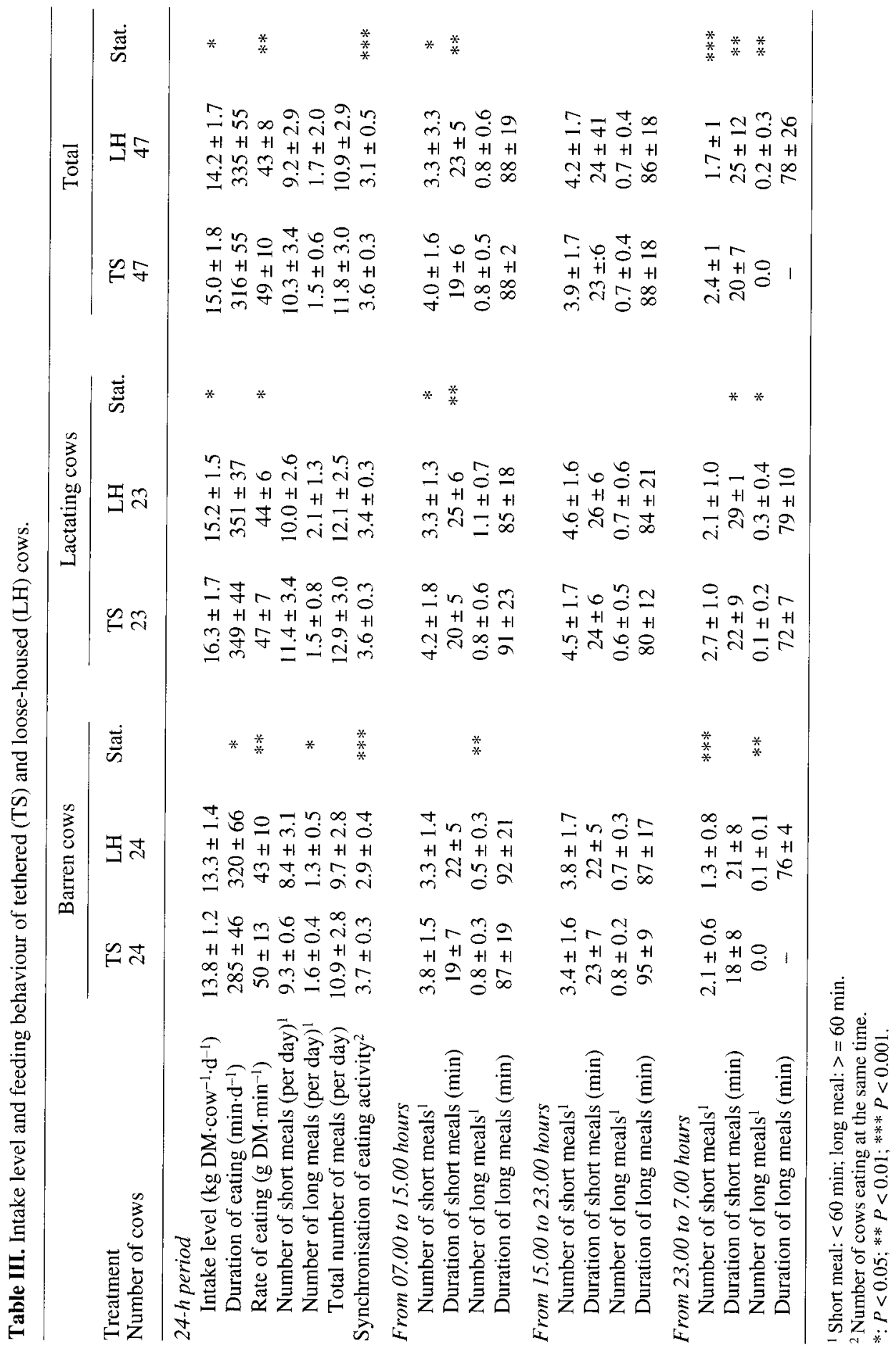




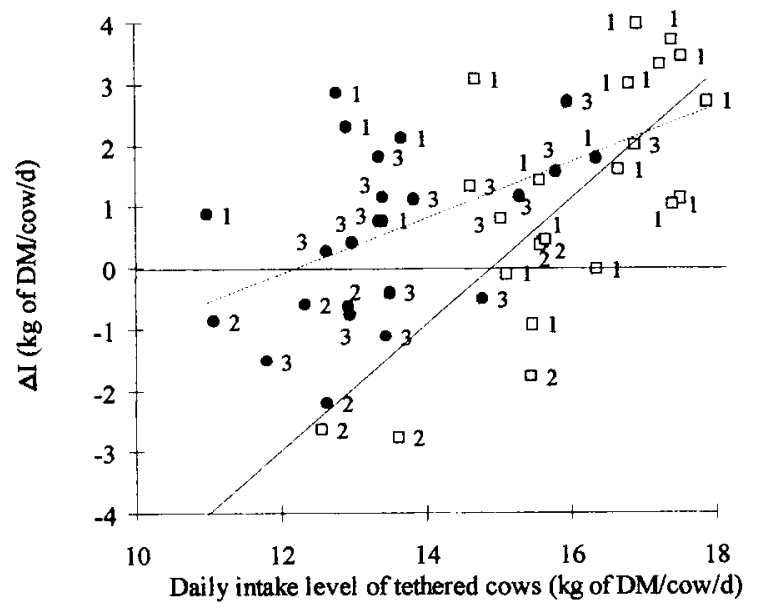

Figure 1. Relationship between the difference of intake $(\Delta \mathrm{I})$ between tie-stall (TS) and loose housing (LH) systems $(\Delta \mathrm{I}=\mathrm{TS}-\mathrm{LH})$ and the daily intake level in the tiestall system (reference) for barren and lactating cows. Numbers correspond to the three groups obtained by using the difference in intake and feeding behaviour between TS and $\mathrm{LH}$ as clustering variables. $\square$ lactating cows; 0 barren cows. meals during the morning and fewer short meals and had some long meals during night when loose-housed. No differences appeared for either the number or duration of meals during the P2 period (from 15.00 to 23.00 hours).

The overall average values of synchronisation of eating activity were 3.4 , indicating that more than half of the cows in a group ate at the same time. The synchronisation of eating activity was greater in the TS system, but the difference was significant $(P<0.001)$ only for barren cows. The difference between barren and lactating cows appeared only in the LH system: loosehoused barren cows had a low synchronisation, with less than three cows eating simultaneously.

Eating duration per hour did not differ between treatments according to the global daily pattern (figure 2 ). Values ranged from 3 to $32 \mathrm{~min} \cdot \mathrm{h}^{-1}$ for tethered cows and from 2 to $35 \mathrm{~min} \cdot \mathrm{h}^{-1}$ for loose-housed cows and in both cases were closely linked with feeding time. Most of the time spent eating followed feeding and there was minimal time spent eating at night.

Finally, differences in feeding behaviour between the TS and LH systems were generally greater for barren cows. When loose- housed, barren cows spent more time eating, they had a lower rate of eating, less long meals and meals were less synchronised, but their intake did not differ. On the other hand, lactating cows had a lower intake when loose-housed and had a lower rate of eating but no other significant differences occurred in their feeding behaviour.

\subsection{Individual variability in differences between tie-stall and loose housing systems}

The multivariate analysis (PCA and cluster analysis) was performed using five variables representing the differences between TS and LH systems for feeding behaviour. Three groups (G1, G2 and G3) were distinguished by the analysis, with 21,9 and 17 cows in groups 1,2 and 3 , respectively. The between-group comparisons were performed for each housing system (table IV). The proportions of the total variation accounted for by the first, second and third principal components (PCA) were 0.35, 0.19 and 0.18 . The first component discriminates cows according to the difference between TS and LH for the number of meals and the synchronisation of eating. The second and third components discriminate cows accord- 


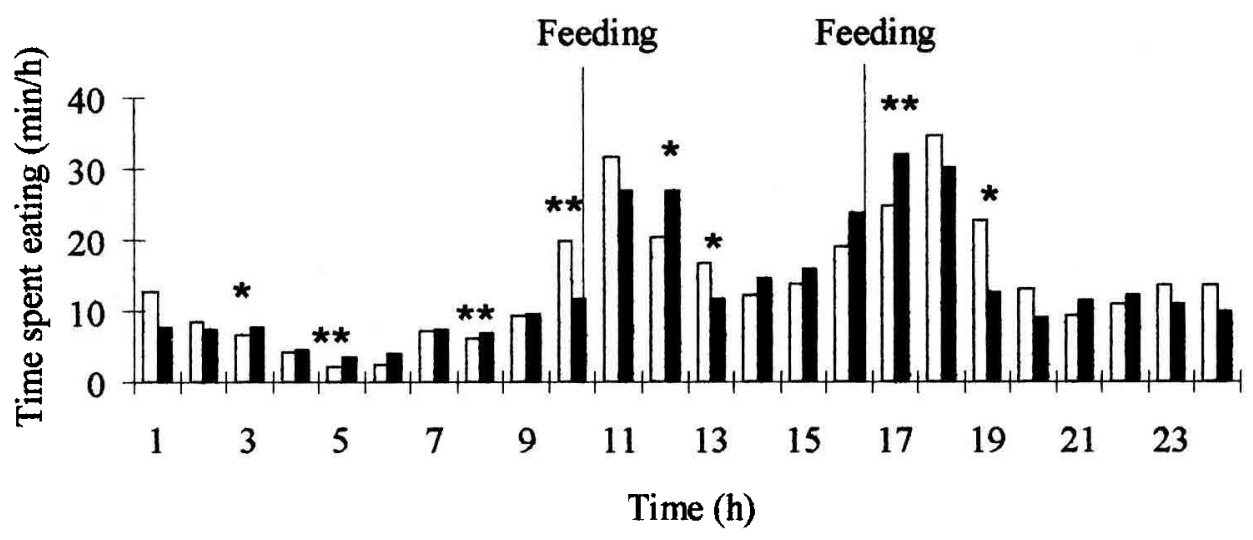

Figure 2. Time spent eating by cows in the tie-stall and loose housing systems.

(* test of Kolmogorov-Smirnov; ${ }^{*} P<0.05 ;{ }^{*} P<0.01$ ). $\square$ loose-housed cows; $\square$ tethered cows.

Table IV. Feeding behaviour: between-group comparison for tethered (TS) and loose-housed (LH) cows.

\begin{tabular}{|c|c|c|c|c|c|c|c|c|}
\hline \multirow{2}{*}{$\begin{array}{l}\text { Treatment } \\
\text { Group }\end{array}$} & \multicolumn{4}{|c|}{ Tethered cows } & \multicolumn{4}{|c|}{ Loose-housed cows } \\
\hline & Gl & G2 & G3 & Stat. & G1 & G2 & G3 & Stat. \\
\hline Intake level $\left(\mathrm{kg} \mathrm{DM} \cdot \mathrm{cow}^{-1} \cdot \mathrm{d}^{-1}\right)$ & 15.6a & $13.5 \mathrm{~b}$ & $14.1 \mathrm{~b}$ & $* *$ & 13.8 & 14.7 & 13.5 & \\
\hline Duration of eating $\left(\min \cdot d^{-1}\right)$ & $337 \mathrm{a}$ & $345 \mathrm{a}$ & $276 \mathrm{~b}$ & $* * *$ & $349 \mathrm{a}$ & $361 \mathrm{a}$ & $305 b$ & $* *$ \\
\hline Number of short meals (per day) ${ }^{1}$ & $12 a$ & $10.4 \mathrm{ab}$ & $8.1 \mathrm{~b}$ & $* * *$ & 8.5 & 8.4 & 10.4 & \\
\hline Number of long meals (per day) ${ }^{1}$ & $1.2 \mathrm{~b}$ & $1.9 \mathrm{a}$ & $1.7 \mathrm{ab}$ & $* *$ & 2.2 & 1.7 & 1.0 & $* *$ \\
\hline Synchronisation of eating activity ${ }^{2}$ & 3.63 & 3.56 & 3.73 & & $3.34 \mathrm{a}$ & $3.46 \mathrm{a}$ & $2.74 b$ & $* * *$ \\
\hline DRE: daily rate of eating $\left(\mathrm{g} \mathrm{DM} \cdot \mathrm{min}^{-1}\right)$ & $49 \mathrm{ab}$ & $41 \mathrm{~b}$ & $53 a$ & $* *$ & 41 & 43 & 46 & \\
\hline
\end{tabular}

Letters indicate significant differences between groups $(*: P<0.05 ; * * P<0.01 ; * * * P<0.001)$ for each treatment (TS and LH).

' Short meal: $<60 \mathrm{~min}$; long meal: $>=60 \mathrm{~min}$.

${ }^{2}$ Number of cows eating at the same time.

ing to the difference between TS and LH for daily duration of eating and daily intake level, respectively. Therefore, the individual modification of intake was not the first discriminating variable, indicating that all cows did not modify their feeding behaviour in the same way and that there were different individual adaptive strategies within the group.

Groups can be described according to some characteristics of the cows as follows (table V):
G1 $(n=21)$ : Lactating cows with a reduced intake when loose-housed. In the G1 group, there was a marked difference in intake between cows in the TS and those in the LH system. This was associated with fewer short meals and more long meals when loose-housed. Those cows were not specific according to their characteristics (table V), except that most of them $(0.71)$ were lactating cows. For most of the cows from G1, the intake level in the TS system was high, ranging from 15 to $18 \mathrm{~kg} \mathrm{DM} \cdot \mathrm{d}^{-1}$ (figure 1 ). 
Table V. Characteristics of cows: between-group comparison (average for tie-stall, TS, and loose housing, LH, systems).

\begin{tabular}{lcccc}
\hline Group & $\mathrm{G} 1$ & $\mathrm{G} 2$ & $\mathrm{G} 3$ & Stat. \\
Number of cows (barren) & $21(6)$ & $9(4)$ & $17(14)$ & \\
\hline Average body weight $(\mathrm{kg})$ & $786 \mathrm{a}$ & $741 \mathrm{~b}$ & $783 \mathrm{a}$ & $*$ \\
Average body condition score $(/ 5)$ & $2.3 \mathrm{ab}$ & $2.1 \mathrm{~b}$ & $2.4 \mathrm{a}$ & $*$ \\
Milk yield of lactating cows $\left(\mathrm{kg} \cdot \mathrm{cow}^{-1} \cdot \mathrm{d}^{-1}\right)$ & $7.9 \mathrm{a}$ & $6.7 \mathrm{~b}$ & $8.5 \mathrm{a}$ & $* *$ \\
Height at withers $(\mathrm{cm})$ & 135 & 134 & 135 & \\
Chest depth $(\mathrm{cm})$ & $76 \mathrm{~b}$ & $75 \mathrm{~b}$ & $78 \mathrm{a}$ & $* * *$ \\
Width at trochanter $(\mathrm{cm})$ & $57 \mathrm{a}$ & $58 \mathrm{a}$ & $55 \mathrm{~b}$ & $*$ \\
Social rank $(1=$ dominant to $3=$ submissive) & 1.8 & 2.1 & 2.1 & \\
\hline
\end{tabular}

Letters indicate significant differences between groups $(*: P<0.05 ; * * P<0.01 ; * * * P<0.001)$ for each treatment (TS and LH).

$\mathrm{G} 2(n=9)$ : Low producing light cows, eating more when loose-housed. Cows from G2 were distinguished mostly by a higher intake when loose-housed and by the same level of synchronisation of eating in the two housing systems. These cows were lighter than the average (40 $\mathrm{kg}$ less) and lactating cows $(0.69)$ had a lower milk yield. The intake level of these cows in the TS system was low, ranging from 11 to $15 \mathrm{~kg} \mathrm{DM} \cdot \mathrm{d}^{-1}$ (figure 1).

G3 ( $n=17)$ : Barren cows, modifying greatly their feeding behaviour when loosehoused. Cows from G3 modified their feeding behaviour (longer duration of eating, more short meals, fewer long meals and a lower level of synchronisation when loosehoused) but not their intake level which was mid-ranged in the TS system (figure 1). Those cows were mostly barren cows $(0.82)$ and high producing lactating cows.

The social rank was very similar for the three groups (table $V$ ).

\section{DISCUSSION}

The intake values for dry and lactating cows correspond to those given for the feed intake capacity of beef cows [24]. They also correspond closely to the values obtained in a previous trial with cows from the same herd eating the same type of hay [13]: 12.8 and $15.7 \mathrm{~kg}$ DM, respectively, during pregnancy and lactation vs. 13.2 and 15.8 in the present study. Intake for tethered cows was positively correlated with size, i.e. body length $(r=0.28)$, height at withers $(r=0.42)$ and body weight $(\mathrm{r}=0.32)$, which is in accordance with Forbes [10]. Duration of eating was negatively correlated with weight, and thus heavy cows tended to eat more in a shorter time. Intake and duration of eating were negatively correlated with adiposity and positively correlated with the number of short meals, illustrating that the motivation for eating depends on body energy reserves [8].

The lower level of synchronisation of eating activity when cows were kept in a group was an unexpected result, according to the concept of social facilitation, defined as "an increase of frequency or intensity of responses or initiation of particular responses, already in an animal's repertoire, when shown in the presence of others engaged in the same behaviour at the same time" (Clayton, 1978, cited by Rook and Penning [25]). Rook and Penning [25] found a greater synchronisation of eating than ruminating or idling for grazing dairy cows, contrasting with a greater synchronisation 
of idling for sheep. These results, combined with the present study, could mean that synchronisation of activities in a group is only closely linked with their duration. In other words, the longer the duration of a particular activity during the day, the greater the probability that it will be synchronised.

Authors comparing individual and group feeding typically indicate a greater intake level when animals are kept in groups. For example, an average increase of $4 \%$ was reported for the intake level of growing cattle kept in groups (bulls and steers) [17]. However, this difference was positive for only two-thirds of the trials. Fischer et al. [9] reported no difference in intake level, nor average daily gain and time spent eating in finishing beef heifers. Likewise, no difference was reported in feed intake of ten dairy cows fed individually or in a group, with five and ten mangers for the group [12]. In the present study, cows ate more slowly when they were kept in a group. The fact that the only food was hay (unchopped) may explain the difference between the present results and the previous reported studies involving silage (maize or grass), which had higher ingestibility and was thus consumed more rapidly $[9,19]$. As the cows needed more time to eat the hay in the present study, they were subsequently more exposed to be disturbed by their counterparts when loosehoused. However, the hays used in the present trial were of good quality and supplies were always higher than requirements regardless of the housing system and the physiological state of the cows (figure 3). One explanation for the lower feed consumption of cows when loose-housed was the greater distance between the lying and feeding areas. Once their nutritional requirements were met, the motivation for eating was too weak to maintain the same intake level as when feed was readily available in TS.

There was a substantial individual variability between tethered and loose-housed cows for intake and feeding behaviour. This

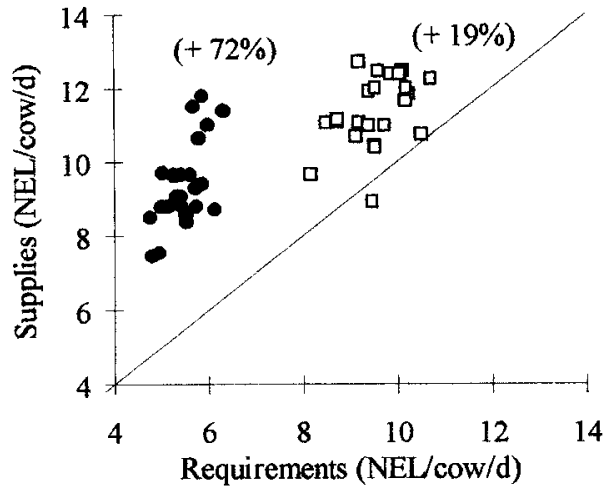

Figure 3. Individual energy balance according to the physiological state of the cows. Requirements $=0.037 \times(\text { liveweight }, \mathrm{kg})^{0.75}+0.44 \times$ milk yield $\left(\mathrm{kg} \cdot \mathrm{d}^{-1}\right)$. $\square$ lactating cows; barren cows.

variability seemed to be dependent upon individual nutritional requirements although supplies were always higher than requirements. Firstly, lactating cows (G1 and G2) modified (i.e. decreased) their intake whereas barren cows (G3) modified their feeding behaviour (i.e. increased the duration of eating, decreased the number of meals and the synchronisation of eating). The relationship between intake in the TS system and the difference of intake between TS and LH systems is not the same for barren and lactating cows (figure 1). Secondly, low producing light cows (G2) increased their intake when loose-housed whereas high producing cows $(\mathrm{G} 1)$ reduced their intake when loose-housed. The former tended to be leaner than the latter, inducing a higher motivation for eating.

\section{CONCLUSION/IMPLICATIONS}

In a loose housing system without competition for food (one manger per animal, ad libitum feeding), cows tended to eat less than in a stanchion system. Although supplies were always higher than requirements, the difference was positively correlated to 
nutritional requirements of cows and was greater for heavy lactating cows which ate $1.8 \mathrm{~kg}$ DM less when they were loosehoused. The modification in feeding behaviour from TS to LH systems differed between barren and lactating cows. The former tended to have more long meals and less short meals when they were loosehoused, with a similar global daily duration of eating (345 min) and a similar number of total daily meals $(n=12)$. The latter tended to have less long meals and more short meals when they were loose-housed, and more total daily meals. One group of cows had higher intake when they were loose-housed (1.1 kg on average). These were the lightest and leanest cows, and those that were lactating had low milk yield. No effect of social rank was detected to explain differences in feeding behaviour in either treatment.

An effect of group feeding was detected on intake and parameters of feeding behaviour of beef cows. Models of animal performance build-up must then be extended to include situations of group management, taking into account the characteristics of the groups and their environment.

\section{ACKNOWLEDGEMENTS}

We thank all the technical staff of Laqueuille for their help with feeding and handling the experimental animals. We thank Christine Durier, from Inra's Biometry Department, for her assistance in statistical analysis.

\section{REFERENCES}

[1] Agabriel J., Petit M., Recommandations alimentaires pour les vaches allaitantes, Bull. Tech. C.R.Z.V. Theix Inra 70 (1987) 153-166.

[2] Agabriel J., Giraud J.M., Petit M., Détermination et utilisation de la note d'état d'engraissement en élevage allaitant, Bull. Tech. C.R.Z.V. Theix Inra 66 (1986) 43-50.

[3] Albright J.L., Nutrition, feeding and calves. Feeding behavior of dairy cattle, J. Dairy Sci. 76 (1993) 485-498.
[4] Andrieu J., Demarquilly C., Valeur nutritive des fourrages : tables et prévision, Bull. Tech. C.R.Z.V. Theix Inra 70 (1987) 61-73.

[5] Coppock C.E., Noller C.H., Crowl B.W., McLellon C.D., Rhykerd C.L., Effect of group versus individual feeding of complete rations on feed intake of lactating cows, J. Dairy Sci. 55 (1972) 325-327.

[6] Corkum M.J., Bate L.A., Tennessen T., Lirette A., Consequences of reduction of number of individual feeders on feeding behaviour and stress level of feedlot steers, Appl. Anim. Behav. Sci. 41 (1994) 27-35.

[7] Davenport D.G., Rakes A.H., McDaniel B.T., Group-fed concentrate-silage blend versus individually-fed concentrates and group-fed silage for lactating cows, J. Dairy Sci. 66 (1983) 2116-2123.

[8] Faverdin P., Agabriel J., Bocquier F., Ingrand S., Maximiser l'ingestion de fourrages par les ruminants : maîtrise des facteurs liés aux animaux et à leur conduite, Renc. Rech. Rum. 4 (1997) 65-73.

[9] Fisher A.D., Shiels P., O’Kiely P., Enright W.J., The effect of restraint and diet on the behaviour of housed beef heifers, in: O' Kiely P., Collins J.F., Storney T. (Eds.), Proceedings of the 23rd Annual Meeting of the Grassland and Animal Production Association, 1997, pp. 251-252.

[10] Forbes J.M., Voluntary food intake and diet selection in farm animals, Centre for Agriculture and Biosciences International, Wallingford, 1995.

[11] Forbes J.M., Jackson D.A., Johnson D.L., Stockill P., Hoyle B.S., A method for the automatic monitoring of feed intake and feeding behaviour of individual cattle kept in a group, Res. Dev. Agric. 3 (1986) 175-180.

[12] Harb M.Y., Reynolds V.S., Campling R.C., Eating behaviour, social dominance and voluntary intake of silage in group-fed milking cattle, Grass Forage Sci. 40 (1985) 113-118.

[13] Ingrand S., Agabriel J., Typology of the evolution of intake by Charolais cows around calving, Anim. Sci. 65 (1997) 361-371.

[14] Ingrand S., Dedieu B., An approach of batching management practices as a contribution to the study of livestock farming systems, in: Dent J.B., McGregor M.J., Sibbald A.R. (Eds.), Proceedings of the 3rd International Livestock Farming Systems Symposium, Wageningen Pers., Aberdeen, Scotland, 1995, pp. 353-356.

[15] Ingrand S., Dedieu B., Diversité des formules d'allotement en élevage bovin viande. Le cas d'exploitations du Limousin, Inra Prod. Anim. 9 (1996) 189-199.

[16] Ingrand S., Vimal T., Fléchet J., Agabriel J., Brun J.P., Lassalas J., Dedieu B., A free access system for the long-term monitoring of individual intake of beef cows kept in a group, in: Gibb M.J. (Ed.), Proceedings of the 9th European Intake Workshop, IGER, Aberystwyth, UK, 1998, pp. 17-20. 
[17] Ingvartsen K.L., Andersen H.R., Space allowance and type of housing for growing cattle. A review of performance and possible relation to neuroendocrine function, Acta Agric. Scand. Sect. A, Anim. Sci. 43 (1993) 65-80.

[18] Jarrige R., Demarquilly C., Dulphy J.P., Hoden A., Journet M., Béranger C., Geay Y., Micol D., Petit M., Robelin J, Le système des unités d'encombrement pour les bovins, Bull. Tech. C.R.Z.V. Theix Inra 38 (1979) 57-79.

[19] Jarrige R., Dulphy J.P., Faverdin P., Baumont R., Demarquilly C., Activités d'ingestion et de rumination, in: Jarrige R., Ruckebusch Y., Demarquilly C., Farce M.H., Journet M. (Eds), Nutrition des ruminants domestiques. Ingestion et digestion, Inra, Paris, 1995, pp. 123-181.

[20] Lebeaux M.O., ADDAD: Guide de l'utilisateur. Association pour le Développement et la Diffusion de l'Analyse des Données, Paris, 1985.

[21] Le Neindre P., Observations sur l'estimation de la production laitière des vaches allaitantes par la pesée du veau avant et après la tétée, Ann. Zootech. 22 (1973) 413-422.

[22] Munksgaard L., Simonsen B., Behavioural and pituitary-adrenal axis. Responses of tethered cows or cows kept in pens with slatted floors, Acta Agric. Scand. Sect. A, Anim. Sci. 45 (1995) $132-138$

[23] Petit M., Agabriel J., Beef cows, in: Jarrige R. (Ed.), Ruminant Nutrition: Recommended Allowances and Feed Tables, John Libbey Eurotext, Paris, 1989, pp. 93-107.

[24] Petit M., Jarrige R., Russel A.J.F., Wright I.A., Feeding and nutrition of the suckler cow, in: Jarrige R., Béranger C. (Eds.), Beef Cattle Production, Elsevier, Amsterdam, 1992, pp. 191-208.

[25] Rook A.J., Penning P.D., Synchronisation of eating, ruminating and idling activity by grazing sheep, Appl. Anim. Behav. Sci. 32 (1991) 157-166.

[26] Rook A.J., Huckle C.A., Synchronization of ingestive behaviour by grazing dairy cows, Anim. Sci. 60 (1995) 25-30.

[27] Statistical Analysis System Institute, SAS/STAT User's Guide Release 6.03 edition, SAS Institute Inc., Cary, NC, USA, 1988.

[28] Veissier I., Le Neindre P., Trillat G., The use of circadian behaviour to measure adaptation of calves to changes in their environment, Appl. Anim. Behav. Sci. 22 (1989) 1-12. 